\title{
The Implementation of Project-Based Learning Model and Audio Media Visual Can Increase Students' Activities
}

\author{
I Gusti Ngurah Hari Saputra*; Soetarno Joyoatmojo; Harini Harini \\ Sebelas Maret University, Indonesia \\ Email: igustisaputra16@gmail.com
}

http://dx.doi.org/10.18415/ijmmu.v5i4.224

\begin{abstract}
This research aims to investigate whether the use of project-based learning assisted by audio visual media can increase students' activities. This research was an action research The object of this research were students in East Nusa Tenggara which are students in SMAK Suria and those in SMA Negeri 1 Atambua The data were collected through observation, interview, document ion and questionnaires technique. This research utilized qualitative and quantitative data analysis. The combination method was convergent parallel mixed methods type that is the researcher collected qualitative and quantitative data at the same time, analysed data separately, and compared the findings to know whether or not those findings complete each other. The result of this research showed that the implementation of PBL assisted by audio visual media in Economics increased learning activities in class XI Social science at SMAK Suria Atambua and class XI social science at SMA Negeri 1 Atambua The results were shown through the improvement of learning activities in which the result of pretest was $41.41 \%$ and the post test was $61.09 \%$ after getting treatment in cycle 1 and increased to $78.91 \%$. This also happened in SMA Negeri 1 Atambua, class XI social science. After implementing PJBL assisted by audio visual media, from $42.59 \%$ it increased to 56.49 in cycle luntil $82.49 \%$ after gettingt treatment in cycle II that is included in high criteria.
\end{abstract}

Keywords: Project Based Learning; Audio Visual; Activities;

\section{Introduction}

Education is an important tool that plays important role. It is a human need that should be fulfilled a long life. In developing the quality of national education there are various ways conducted to reduce educational problem such as curriculum renewal, developing teacher quality and education facilities. Therefore, teacher play important role in learning process. The implementation of innovative media and model might improve students' learning activities. Pabloz, Pazo, \& Repiso (2017) argued that to make students be active in learning and have motivation to learn is the real challenge for an experienced teacher. 
Technology and knowledge advancement brings bid influence in education world. Learning process is pressured to use maximal media and model to give positive influence in students' learning outcome. Learning media and model influence both teacher and students in teaching and learning process. The problems in learning process are that students tend to be passive, students' low motivation, conventional teaching method, and lack of learning media. These trigger dissatisfied students' learning outcome. Therefore, it needs innovative learning for teacher and students. The implementation of projected based learning model assisted by audio visual media is expected will be a solution for those problems.

Project based leaning model is an exclusive teaching technique and it is different from the conventional one. Since project based learning model increase students' learning habit and create new learning practice because students have to think originally for real life problem solving Tasci (2015) stated that learning approach based project has been an educational approach with its superiority that is students as learning centre. Project based learning give more opportunity for the students to be active in learning activities as well as learn new soft skills such as collaboration, communication and negotiation. The implementation of project based learning will be easier if it is collaborated with media (Williams 2017). In this research, the media used was audio visual media. Audio visual media is a media requiring sight and hearing at the same time. Information and message that are gotten by the students are verbal and non verbal messages. One of audio visual media is video. According to Smaldino, Russell, Heinich, \& Molenda (2005), video is an electronic storage tool such as moving image, recording, etc. In Roman, video means "I see" so that, the format of video is using move image to show the message. Based on those explanations, the objective of this research is to investigate the implementation of project based learning model assited by audio visual can increase students' learning outcome.

\section{Literature Review Project Based Learning Model}

Project based learning can be defined as learning model that can push the students to be active, creative and productive to increase students' learning outcome optimally. Warsono \& Haryanto (2012) argued that project based learning is developed by active learning theory from John Dewey's concept and constructivism theory from Jean Piaget. In addition, project based learning is the implementation of active learning. Project based learning is one of typical learning technique and it is different from common learning techniques. Since, project based learning increase students' learning habit and new learning practice.

Project based learning approach has been an educational approach with its superiority that is students as the centre of learning (Tasci., 2015). Project based learning give students the opportunity to get involved in learning and learn new soft skills such as collaboration, communication and negotiation. (Williams., 2017) Keser \& Karahoca (2010); Chu, Zhang, Chan, Lee, Zou. \& Lau (2017) stated that project based learning has constructivism characteristic to create knowledge and resolution, and give the freedom to work with a set time. Project based learning is also based on real life issues so that, the basis of project management can be considered in the perspective of the project based learning process, in which students can learn by taking an active role in projects, (Krajcik \& Blumenfeld dalam Santrock., 2009). This approach is widely believed to be a strong teaching strategy that will enhance students' motivation and promote themselves through learning. The learning process of PJBL is that students can form the same small groups to collaborate with another, thereby students can achieve integrated and collective output during the learning process, (Blumenfeld et. al in Kaser \& Karahoca., 2010).

Efstratia (2014) stated that in project learning the teacher plays the role as a facilitator to construct useful questions, devise meaningful tasks, train the development of knowledge, social skills, and assess carefully what students have learned from experience. Project work contains very complex 
tasks based on questions and problems (challenges) that challenge and demand students to design, solve problems, make decisions, make investigative activities, and provide, the opportunity for students to be able to work independently, (Cuma., 2013; Filho., Shiel., \& Paco., 2016). This leads to project-based learning to be a learning that motivates the individual student according to the level of development of his or her personal skills.

Kamdi (2008) pointed out the stages in project based learning as follow:

\section{1) Start With the Essential Question}

Learning begins with the essential question, which is the question can give the student assignment to perform an activity. Take topics that are in line with real-world reality and begin with an in-depth investigation. Teachers try to keep the topics relevant for the students.

\section{2) Design a Plan for the Project}

Planning is done collaboratively between teachers and students, so students are expected to feel ownership of the project. Planning contains the rules of the game, the selection of activities that can be supportive in answering essential questions by combining possible subjects, and knowing the tools and materials that can be accessed to assist project completion.

\section{3) Create a Schedule}

Teachers and students jointly develop a schedule of activities in completing the project. The activities in this stage include:

a) Making time line for project accomplishment,

b) Making deadline of project completion,

c) Bringing students to plan new ways,

d) Guiding students when they make a non-project-related way, and

e) Asking students to make an explanation (reason) about choosing a way

\section{4) Monitor the Students and Progress of the Project}

Teacher takes responsibility to monitor students' activities in completing the project. Monitoring is conducted by facilitating students in each process. In other words, the teacher plays a role as a monitor of students' activities. To simplify the monitoring process, rubric is made to record the whole activity. 


\section{5) Assess the Outcome}

Assessment is done to assist the teacher in measuring standard achievement, evaluating each student's progress, providing feedback on the level of competence that has been achieved by the students, and in preparing the next learning strategy.

\section{6) Evaluate the Experience}

At the end of learning process, teacher and students will conduct a reflection on the activities and project results. The reflection process is done both individually and in groups. In this stage, the students are asked to express their feelings and experiences during project completion. Teachers and students develop discussions in order to improve performance during the learning process, so that a new inquiry is finally found to answer the problems posed at the first stage of learning.

\section{Audio Visual Media}

According to Hujair (2009), audio visual media is a set of tools that have a function to project moving and voiced images. In audio visual media, the combination of images and sounds produces the same character as the original object. Additionally, Anitah (2011) pointed out that audio visual media is a medium that is not only seen or heard only, but also simultaneously can be seen and heard or something visualized. According to Smaldino, Russell, Heinich, \& Molenda (2005), video is an electronic storage tool such as moving image, recording, etc. The video in Latin means "I see" so that, the video format is to use a moving image to show the message.

Fevre (2003) argued that video is a medium that can be developed into resources and used in special ways to improve learning. The use of video in learning does not only enhance students' learning experience, but also gives additional experience for the teacher, (Brunvand., 2010). Smaldino, Russell, Heinich, \& Molenda (2005) stated that the use of learning videos can replace the teacher, but the video media can assist the teacher to be a creative instructor in learning process. Video is the perfect medium to give exposure to the example of learning materials that are presented. Costke \& Lange (2017) argued that learning video media does not only enhances learning experience, but also has a positive impact on student decision making.

According to Riyana (2001), media video learning as teaching materials aims to:

1. Clarifying and delivering messages so as not to be too verbal.

2. Overcoming the limitations of time, space and sensory power of students and teachers.

3. Can be used varied.

Audio visual media is a media that has elements of sound and image elements. Audio visual media has better capabilities because it covers both types of audio and visual media. Audio-visual media is an audio visual tool which means materials or tools used in learning situations to assist writing and material delivered in order to transmit knowledge, attitudes, and ideas. Learning by using audio-visual media is a way of learning that contains elements of sound and image where the process of delivering the material involves the sense of sight and the sense of hearing. 


\section{Learning Activities}

Roussseau in Sardiman (2009) provided the view that learning activity is a knowledge that must be obtained by self-observation, experience experienced alone. This shows that in the learning process every person must be active by itself because without any activity it will not happens an optimal learning process. Pang in Paolini (2015) argued that to further stimulate student, teachers can use activity-based learning strategies that empower students to improve meta cognitive skills by applying classroom information that impact on improving student knowledge. By using activity-based learning strategies students are expected to be responsible for the learning and material implementation by the students themselves.

According to Jessica (2009), the factors that affect the active students in learning are:

1) Internal factor: this factor is emphasized on individual factor. The factors that affect these activities are psychological factors, namely: motivation, attention, observation, responses and so forth.

2) External factors: the achievement of learning objectives needs a conducive learning environment system. This relates to outside factors of the student. The other influencing factors are gaining knowledge, planting concepts, skills and attitude formation.

\section{Methodology}

This research utilized qualitative and quantitative data analysis. The combination method was convergent parallel mixed methods type that is the researcher collected qualitative and quantitative data at the same time, analysed data separately, and compared the findings to know whether or not those findings complete each other. The main techniques of data collection in this reseacrh were: interview and observation. Samples in this study where 70 students in Atambua, East Nusa Tenggara.

\section{Results}

Results show that students are very active and make a very large contribution during the learning process. It is different from the previous activities tin which the teacher as a learning centre and students only give a little contribution. A change of the learning centre occurred after giving the action that makes the student as the centre of learning. This happens because learning is presented using project based learning method with audio-visual visual media which required students to think and act alone with teacher's guidance who acts as a facilitator, so that students can experience their own individual and group learning experiences. This is in line with Gondium and Mutti (2011) who pointed out that to make students active in the learning process is by transforming the process into an experience that allows students to reflect on their own and ultimately allow them to make their own improvements to what they do. From several findings, it can be concluded that the application of project based learning model assisted by audio visual media impact on students' learning activities improvement. This can be seen from the comparison of learning activities improvement in pre-action, cycle 1 and cycle 2 as in the table below: 
Table 1 Comparison of observation sheet of student activity activity of class XI SMAK Suria Atambua

No Indicator

Pre-cycle Cycle $1 \quad$ Cycle 2

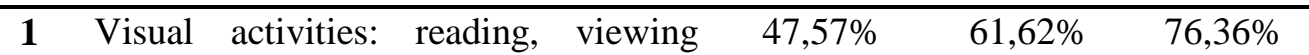
pictures, observing and demonstrating

2 Oral activities: proposing a fact, connecting an event, asking questions,

$39,46 \% \quad 55,68 \% \quad 68,48 \%$ giving advice and expressing opinions.

3 Listening activities: listening to

$48,11 \% \quad 64,87 \% \quad 92,72 \%$ material presentation, listening to discussion conversation

4 Writing activities: writing reports, $39,46 \% \quad 58,38 \% \quad 78,18 \%$ checking essays, copying materials, making outlines or summaries, doing tests and filing questionnaires.

5 Mental activities are contemplating, remembering, solving problems, analyzing factors, looking at relationships and making decisions.

$32,44 \% \quad 64,87 \% \quad 78,79 \%$

\begin{tabular}{cccc}
\hline Total & $207,03 \%$ & $305,41 \%$ & $394,54 \%$ \\
\hline Mean & $41,41 \%$ & $61,09 \%$ & $78,91 \%$ \\
\hline
\end{tabular}


Table 2 Comparison of observation sheet of students' activity in class XI XI SMAK 1 Atambua

\begin{tabular}{lllcc}
\hline No & \multicolumn{1}{c}{ Indicator } & Pre-cycle & Cycle 1 & Cycle 2 \\
\hline $\mathbf{1}$ & $\begin{array}{l}\text { Visual activities: reading, viewing pictures, } \\
\text { observing and demonstrating }\end{array}$ & 48.65 & 62.16 & 84.32 \\
$\mathbf{2}$ & $\begin{array}{l}\text { Oral activities: proposing a fact, connecting } \\
\text { an event, asking questions, giving advice } \\
\text { and expressing opinions. }\end{array}$ & 41.62 & 59.46 & 79.46 \\
$\mathbf{3} \quad \begin{array}{l}\text { Listening activities: listening to material } \\
\text { presentation, listening to discussion } \\
\text { conversation }\end{array}$ & 48.11 & 65.40 & 83.24 \\
$\mathbf{4} \quad \begin{array}{l}\text { Writing activities: writing reports, checking } \\
\text { essays, copying materials, making outlines } \\
\text { or summaries, doing tests and filing } \\
\text { questionnaires. }\end{array}$ & 40.54 & 59.46 & 78.92 \\
$\begin{array}{l}\text { Mental activities are contemplating, } \\
\text { remembering, solving problems, analyzing } \\
\text { factors, looking at relationships and making } \\
\text { decisions. }\end{array}$ & 34.05 & 65.94 & 86.49 \\
\hline
\end{tabular}

(Source: Primary data processed, 2017)

\section{Conclusion}

It can be concluded that the implementation of project based learning model assisted by audiovisual media can increase the activity of students at SMAK Suria Atambua and SMA Negeri 1 Atambua class XI Social Science Education. Activity improvement and learning outcomes are shown by changes in students' behaviour and attitude in learning. The improvement of learning activities is reviewed from every aspect in SMAK Suria Atambua class XI IPS namely: 41,41\% for pre action, cycle I reached $61,09 \%$ and cycle II reached 78,91\%. In SMA Negeri 1 class XI IPS 2, the value of pre action is $42,59 \%$, cycle I reached $62,45 \%$ and cycle II reached $82,49 \%$. The results of this study shows that the implementation of project based learning model has an impact on the improvement of student learning activities that continue to reveal in each learning cycle 


\section{References}

Brunvand, S. (2010). Best Practices for Producing Video Content for Teacher Education. Contemporary Issues in Technology and Teacher Education, 10(2): 247-256.

Chu, W, S, K. Zhang, Y. Chan, K, C. Lee, Y, C, W. Zou, E. \& Lau, W. (2017). The Effectiveness of Wikis for Project-Based Learning in Different Disciplines in Higher Education. Internet and Higher Education, 33: 49-60.

Costke, J \& Lange. H.C. (2017). Effects of Viewership and Media Diversity on Learning, Satisfaction, Engagement, Interest, and Future Behavioral Intetion. Interactive Technology and Smart Education 14: 14-30.

Cuma, I. F. (2013). Project-Based Learning in Teaching with the DAF Montessori Method. Social and Behavioral Sciences, 70: 1901-1910.

Efstratia, D. (2014). Experiential Education Through Project Based Learning. Procedia Social and Behavioral sciences, 152: 1256-1260.

Fevre. L. M. D. (2015). Designing for Teaching Learning Video Based Curriculum Desin. Using video in teaching education. 09: 235-258.

Gondium, S. M. G., dan Mutti, C. (2011). Affection in Learning Situatioan: a Study of an Entrepreneurship Skill Development Course. Journal of Workplace learning, 23(3): 195-208.

Hujair, S. (2009). Media Pembelajaran. Yogyakarta: Safiria Insania Press.

Jessica. (2009). Factor-Faktor Yang Memegaruhi Pembelajaran. Bandung: Indah Harapan.

Kamdi, W. (200). Project Based Learning: Pendekatan Pembelajaran Inovatif. Makalah.Disampaikan dalam Pelatihan Penyusunan BahanAjar Guru SMP dan SMK Kota Tarakan, 31 Oktober 2 November 2008. Universitas Negeri Malang.

Keser, H \& Karahoca, D. (2010). Desingning a Project Management E-course by Using Project Based Learning. Prodcedia Social And Behavioral sciences. 2: 5744-5754.

Pablos, G, V, B. Pazo, D. M. M. Repiso, M, A, G. (2016). Project based learning (PBL) Through the Incorporation of Digital Technologies: an Evaluation Based on the Experience of Serving Teacher. Computers in human Behavir. 68: 501-512.

Paolini, A. (2015). Enhancing Teaching Effectiveness and Student Learning Outcomes. Journal of effective teaching, 15(1): 20-33.

Riyana, C. (2007). Pedoman Pengembangan Media Video. Jakarta: P3AI UPI.

Sadiman, S. A. Rahardjo. R., Haryono. A, \& Rahardjito. (1993). Media Pendidikan Pengertian, Pengembangan, dan Pemanfaatan. Jakarta: PT Raja Grafindo persada.

Santrock, J. W. (2014). Psikologi Pendidikan. Jakarta: Salemba Humanika.

Smaldino, S. E. Russell. J. D. Heinich, R. Molenda, M. (2005). Instructional Technology and Media for Learning. Upper Saddle River: Pearson Education Inc.

Tasci, B. G. (2015). Project based learning From Elementary School to College, Tool: Architecture. Social and behavioral sciences, 186: 770-775. 
Warsono \& Hariyanto. (2012). Pembelajaran Aktif. Bandung: PT Remaja Rosdakarya.

Williams, S. (2017). Investigating the Allocation and Corroboration Of Individual for Project-Based Learning. Student in Educational Evaluatio, 53: 1-9.

\section{Copyrights}

Copyright for this article is retained by the author(s), with first publication rights granted to the journal.

This is an open-access article distributed under the terms and conditions of the Creative Commons Attribution license (http://creativecommons.org/licenses/by/4.0/). 